\title{
Ірина ЧИРАК
}

кандидат економічних наук, доцент, Тернопільський національний економічний університет, Тернопіль, Україна, chyrak.iryna@gmail.com

ORCID ID: 0000-0003-1593-7042

\section{ФIНАНСОВА СТАБІАЬНІСТЬ, ФIHAHСОВА НЕСТАБIАЬНICТЬ I ФIHAHСОВА СТІЙКІСТЬ ЕКОНОМІКИ}

Вступ. В умовах лібералізації зовнішньоекономічних зв'язків, послаблення державного контролю за рухом капіталу, прискорення глобалізаційних процесів у фрінансовокредитній сфрері значно підвищилася фрінансова нестабільність, яка послабила стійкість національних економік і зробила їх більш вразливими до кризових шоків. Значні втрати економіки від кризових явищ посилюють потребу в дослідженні суті фрінансової нестабільності і стійкості економіки, чинників, що впливають на їх стан, виявлення передкризових ризиків.

Мета - узагальнити теоретичні підходи до визначення сутності фрінансової стабільності, фінансової нестабільності та фрінансової стійкості, виявити чинники, які впливають на їх стан, а також визначити особливості забезпечення фрінансової стійкості економіки за умов пандемії Covid-19.

Mетоди. У дослідженні сучасних теоретичних підходів стосовно визначення сутності фрінансової стабільності та фрінансової стійкості економіки використано низку загальнонаукових і спеціальних методів дослідження, зокрема: аналіз, синтез, індукцію, дедукцію, абстрактно-логічний та узагальнення.

Результати. Розглянуто й узагальнено теоретичні підходи щодо визначення сутності фрінансової стабільності та фрінансової стійкості економіки. Встановлено, що вони є взаємопов'язаними і взаємозалежними між собою явищами і найважливішими умовами стабільного розвитку національної економіки. Проаналізовано погляди вчених і дослідників на сутність фрінансової нестабільності, причини їі виникнення і можливі негативні наслідки для економіки. Встановлено, що переважна більшість вчених пов'язують нестабільність із нездатністю фрінансової системи протистояти шокам і перешкоджати їх руйнівному впливу на реальну економіку. З'ясовані чинники, які можуть зумовити фрінансову нестабільність, і що вплив кожного з них на певний момент часу може бути визначальним.

Акцентовано увагу на наростанні ризиків виникнення і розгортання кризових явищ, як у світовій, так і національних економіках в умовах пандемії коронавірусу (Covid-19), а також на важливості надання державної підтримки господарюючим суб'єктам і галузям для їх адаптації до обставин, що склалися.

() Ірина Миколаївна Чирак, 2020 
Перспективи. В подальших наукових дослідженнях пропонується зосередити увагу на виробленні та ефрективному використанні заходів, спрямованих на підвищення фінансової стійкості економіки, які даватимуть можливість мінімізувати негативний вплив шоків і підтримувати стабільно зростаючу економічну динаміку.

Ключові слова: фрінансова стабільність, фрінансова стійкість економіки, фрінансова нестабільність, кризові явища, чинники фрінансової нестабільності, чинники стійкості економіки.

Бібл.: 20.

\section{Ирина ЧИРАК}

кандидат экономических наук, доцент, Тернопольский национальный экономический университет, Тернополь, Украина

\section{ФИНАНСОВАЯ СТАБНАЬНОСТЬ, ФИНАНСОВАЯ НЕСТАБИАЬНОСТЬ И ФИНАНСОВАЯ УСТОЙЧИВОСТЬ ЭКОНОМИКИ}

Введение. В условиях либерализации внешнеэкономических связей, ослабления государственного контроля за движением капитала, ускорения глобализационных процессов в финансово-кредитной сфере значительно повысилась фринансовая нестабильность, которая ослабила устойчивость национальных экономик и сделала их более уязвимыми к кризисным шокам. Значительные потери экономики от кризисных явлений усиливают потребность в исследовании сущности фринансовой нестабильности и устойчивости экономики, фракторов, влияющих на их состояние, выявление предкризисных рисков.

Цель - обобщить теоретические подходы к определению сущности фринансовой стабильности, финансовой нестабильности и фринансовой устойчивости, выявить факторы, влияющие на их состояние, а также определить особенности обеспечения фринансовой устойчивости экономики в условиях пандемии Covid-19.

Методы. При исследовании современных теоретических подходов к определению сущности финансовой стабильности и финансовой устойчивости экономики использован ряд общенаучных и специальных методов исследования, в частности: анализ, синтез, индукцию, дедукцию, абстрактно-логический и обобщения.

Результаты. Рассмотрены и обобщены теоретические подходы к определению сущности фринансовой стабильности и финансовой устойчивости экономики. Установлено, что они взаимосвязаны и взаимозависимы между собой и являются важнейшими условиями устойчивого развития национальной экономики. Проанализированы взгляды ученых и исследователей на сущность финансовой нестабильности, причины ее возникновения и возможные негативные последствия для экономики. Установлено, что подавляющее большинство ученых связывают нестабильность с неспособностью финансовой системы противостоять шокам и препятствовать их разрушительному воздействию на реальную экономику. Выяснено наличие большого количества фракторов, которые могут вызвать фринансовую нестабильность, и тот фракт, что влияние каждого из них на определенный момент времени может быть определяющим. 
Акцентировано внимание на нарастании рисков возникновения и развертывания кризисных явлений, как в мировой, так и национальных экономиках в условиях пандемии коронавируса (Covid-19) и важности предоставления государственной поддержки хозяйствующим субъектам и отраслям для их адаптации к сложившимся обстоятельствам.

Перспективы. В дальнейших научных исследованиях предлагается сосредоточить внимание на выработке и эфрфективном использовании мер, направленных на повышение фринансовой устойчивости экономики, позволяющих минимизировать негативное влияние шоков и поддерживать стабильно растущую экономическую динамику.

Ключевые слова: финансовая стабильность, фринансовая устойчивость экономики, фринансовая нестабильность, кризисные явления, фракторы фринансовой нестабильности, фракторы устойчивости экономики.

\section{Iryna CHYRAK}

Ph. D (Economics), Assoc. Prof., Ternopil National Economic University, Ternopil, Ukraine, chyrak.iryna@gmail.com

ORCID ID: 0000-0003-1593-7042

\section{FINANCIAL STABILITY, FINANCIAL INSTABILITY AND FINANCIAL SUS- TAINABILITY OF THE ECONOMY}

Introduction. The financial instability has significantly increased due to the liberalization of foreign economic relations, the weakening of state control over the movement of capital and the acceleration of globalization processes in the financial and credit sphere. It has weakened the sustainability of national economies and made them more vulnerable to crisis shocks. Significant economic losses from crisis phenomena increase the need for research of the nature of financial instability and sustainability of the economy, the factors affecting its condition and the identification of pre-crisis risks.

Issues of developing and effectively utilizing measures aimed at improving the financial stability of the economy remain relevant. It will minimize the negative impact of shocks and maintain steadily growing economic dynamics.

The purpose is to generalize theoretical approaches in order to determine the essence of financial stability, financial instability and financial sustainability, to identify factors affecting it, and also to define the peculiarities of providing financial sustainability of the economy in conditions of Covid-19 pandemic.

Methods. It has been used a number of scientific and special methods of the research such as: analysis, synthesis, induction, deduction, abstract, logic and generalization methods while studying the modern theoretical approaches to determine the nature of financial stability and financial stability of the economy, identifying the interdependencies between them, analyzing of scientists' views on the nature of financial instability, the causes of its occurrence and possible negative consequences for the economy.

Results. Theoretical approaches to determining the essence of financial stability and financial stability of the economy have been considered and generalized. It has been established that they are interrelated and interdependent phenomena and the most important conditions for stable development of the national economy. The views of scientists and researchers on the nature of fi- 
nancial instability, the causes of its occurrence and possible negative consequences for the economy have been analyzed. It has been found that the vast majority of scientists associate instability with the inability of the financial system to withstand shocks and prevent their devastating impact on the real economy. It has been determined that there are many factors that can cause financial instability and the impact of each of them at some point in time can be significant.

It has been emphasized on increasing risks of crisis emergence and deployment in both global and national economies in the conditions of the Covid-19 pandemic and the importance of providing government support to businesses and industries to adapt to evolving circumstances.

Conclusions. Further research suggests focusing on the development and effective use of measures aimed at improving the financial sustainability of the economy, which will minimize the negative impact of shocks and maintain a steadily increasing economic dynamic.

Keywords: financial stability, financial sustainability of the economy, financial instability, crisis, factors of financial instability, factors of sustainability of the economy.

JEL Classification: E39; G01; 011.

Постановка проблеми. Лібералізація зовнішньоекономічних зв'язків, послаблення державного контролю за рухом капіталу, глобалізаційні процеси у фінансово-кредитній сфері посилили фінансову нестабільність і послабили стійкість національних економік, зробивши їх більш вразливими до кризових шоків. За цих умов особливої актуальності набуває проблема дослідження сутності економіки та чинників, що впливають на їх стан.

Значні втрати економіки від кризових явищ посилюють потребу в дослідженнях, спрямованих на оцінку стану фрінансової нестабільності, виявлення передкризових ризиків і вироблення та використання заходів для досягнення фінансової стійкості економіки, яка дасть змогу мінімізувати негативний вплив шоків і підтримувати стабільно зростаючу економічну динаміку.

Аналіз останніх досліджень і публікацій. Сутність, умови та причини настання і наслідки таких феноменів, як фрінансова стабільність, фрінансова стійкість економіки та фінансова нестабільність, є пильним об'єктом досліджень зарубіжних і вітчизняних вчених, аналітиків і експертів міжнародних фрінансових інститутів, центральних банків та урядів провідних країн світу. Серед великої кількості досліджень західних економістів доцільно виокремити роботи І. Фішера [1], Х. Мінскі [2], Л. Крокетта [3], Р. Лагунофа [4], Я. Крегеля [5], С. Шрьодера [6], О. Аспеча [7], М. Райха [8]. Ці аспекти досліджують такі вітчизняні вчені, як: Я. Белінська [9], І. Скрипниченко [10], А. Бойко [11], В. Коваленко [12], Т. Унковська [13], П. Шпік [14], І. Крючкова [15] та інші.

Метою статті $€$ узагальнення теоретичних підходів до визначення сутності фрінансової стабільності, фрінансової стійкості економіки та фрінансової нестабільності, виявлення чинників, які впливають на їх стан, а також визначення особливостей забезпечення фрінансової стійкості за умов пандемії коронавірусу (covid-19).

Виклад основного матеріалу дослідження. "Фінансова стабільність”, “фрінансова нестабільність" та "фрінансова стійкість економіки" є складними і дискусійними поняттями у дослідженнях зарубіжних і вітчизняних вчених, аналітиків та спеціалістів міжнародних фрінансових інститутів, урядів і центральних банків провідних країн світу. Передумовами початку їх дослідження були посилення кризових явищ і виник- 
нення фрінансових дисбалансів, спричинених глобалізаційними процесами і значною лібералізацією руху капіталів в останній чверті XX ст. Помітне посилення інтересу до дослідження фрінансової нестабільності відбулося в 90-х роках XX ст. у зв'язку зі збільшенням кількості фрінансових криз у світі і їх значними негативними наслідками як для окремих національних економік, так і для світової економіки в цілому. В цей період розробили цілу низку програм, спрямованих на посилення фрінансової стабільності і визначення вразливих місць фрінансової системи. Міжнародні фрінансові інститути, провідні банки країн світу вдосконалюють стандарти макроекономічної політики, здійснюють аналіз ризиків фрінансової нестабільності, запроваджують індикатори-передвісники настання криз. Проте всі ці зусилля не змогли захистити від появи нових криз з їх суттєвими негативними наслідками. Це свідчить про відсутність системного бачення як самої сутності "фрінансової нестабільності”, так і механізмів, що ії̈ породжують.

Світова фрінансова криза 2008-2009 рр. наглядно продемонструвала, що жодна країна в глобалізованому світі не застрахована від ризиків, які пов'язані з нестабільністю фрінансово-економічної системи. Значні втрати економік від кризових явищ посилюють потребу в дослідженнях, спрямованих на виявлення передкризових ризиків і прийняття випереджувальних заходів з їх запобігання або зниження.

В чисельних дослідженнях зарубіжні та вітчизняні вчені зосереджують свою увагу на таких взаємопов'язаних і взаємозалежних поняттях, як “фінансова стабільність”, "фрінансова нестабільність" і “фрінансова стійкість економіки”. Практично майже всі науковці категорію “фінансова стабільність” зводять до дієвого механізму, який запобігає виникненню криз та сприяє по- дальшому розвитку економіки країни. При цьому поняття "стійкість" і “стабільність" ототожнюють і вважають одними 3 найважливіших умов розвитку національних економік. Під фрінансовою стабільністю розуміється такий стан рівноваги у функціонуванні системи, "за якої фрінансова система ефективно виконує свої ключові економічні функції.., а також здатна робити це у випадку виникнення шоків, стресових ситуацій і в періоди глибоких структурних змін" [16].

Окремі економісти визначають фрінансову стабільність як комплексне поняття, з багатьма аспектами: "Стан, за якого фрінансова система спроможна витримувати порушення і при цьому не допускати кумулятивних процесів, які можуть завдати шкоди заощадженням, інвестуванню та здійсненню платежів в економіці" [17]. Водночас, Г. Херреро, Н. Симон вбачають у фрінансовій стабільності недопущення виникнення криз, насамперед банківських, і слабку зміну ціни активів [18], а П. Шпіка розглядає фінансову стабільність як процес, що містить достовірну оцінку фрінансових ризиків та ефективну систему управління ними [14].

На думку Я. Белінської, фрінансова стабільність - це властивість фрінансової системи з мінімальними витратами змінювати основні характеристики розвитку відповідно до трансформацій економічної системи та зовнішніх впливів [9, с. 73], а з точки зору В. Коваленко, фрінансова стабільність характеризує ступінь досягнення результату, заданого функцією системи [12, с. 128].

Фінансова стійкість переважно розглядається як властивість фінансової системи повертатися до рівноважного стану після припинення впливу негативних чинників. Водночас, окремі вчені ототожнюють ці два поняття і розглядають їх значно ширше, не зводячи лише до стану фінансової системи. Зокрема, Т. Унковська під фрінансовою 
стабільністю розуміє такий стан функціонування фрінансової системи, коли вона перебуває в динамічній ринковій рівновазі або в разі екзогенних чи ендогенних шоків ії відхилення від рівноваги лежить у заданих межах і вона здатна повернутися в режим фінансової рівноваги [13, с. 22-23].

Щодо поняття "фрінансова нестабільність”, то його переважно вживають поруч із поняттями "фінансова криза”, "вразливість фрінансової системи” та "системний ризик". Десініція терміна "фрінансова нестабільність” тлумачиться по-різному і плюралізм поглядів обумовлений як історичним контекстом, так і відповідним теоретичним підходом, обраним для його інтерпретації.

У зарубіжній науковій література фінансова нестабільність, насамперед, пов'язується із настанням ситуації, за якої функціонування економіки потенційно погіршується коливаннями цін фрінансових активів або нездатністю фінансових інститутів виконувати свої договірні зобов'язання; ... фрінансова система не здатна протистояти шокам і перешкоджати їх руйнівному впливу на реальну економіку [3]. На переконання І. Фішера, фрінансова нестабільність тісно пов'язана з динамікою сукупної заборгованості в економіці. Нагромадження надто високої заборгованості в реальному секторі призводить до порушення рівноваги, для відновлення якої необхідно погасити заборгованість. На думку вченого, основною причиною виникнення фрінансової нестабільності $€$ негативна динаміка фундаментальних показників [1].

Х. Мінскі вважає, що фінансова нестабільність закладена в природі ринкових відносин. Подібно І. Фішеру, він пов'язує фінансову нестабільність із виникненням боргу та його знеціненням через придбання спекулятивних фрінансових активів. Рівень же фрінансової нестабільності економіки залежить від форм фрінансування інвестицій, що обирають фрірми (забезпечене фрінансування; спекулятивне фрінансування; понціфрінансування) [2].

В окремих дослідженнях фрінансову нестабільність пов'язують із недосконалістю фінансових ринків, що генерується 3 асиметричністю інформації, яка доступна кредиторам і позичальникам відносно один одного на фрінансових ринках. За умов недосконалості ринків знижується рівень інвестування в реальний сектор економіки і зменшується виробництво продукції, що з часом породжує шоки на фрінансових ринках. Спрямування коштів не на інвестиції в реальний сектор економіки, а під угоди з фрінансовими похідними інструментами призводить до відриву доходів від ціни та стану реальних активів і прибутків корпорацій реального сектору економіки [10, с. 374]. Економіка зі стану стабільності “переходить” у нестабільний стан. При цьому фінансова система стає головним осередком глобальної економічної нестабільності. Відрив важливих економічних параметрів пропозиції грошей, цін і валютних курсів від реальної економічної основи істотно підсилює нестабільність [10, с. 589-590].

Відомі зарубіжні вчені Ф. Мішкін, А. Крокетт, Ф. Аллен, Р. Лагунофр і С. Шрефт поняття “фінансова нестабільність” пов'язують із чутливістю фрінансової системи до виникнення великих фрінансових криз. Чинниками, що спричиняють нестабільність системи, можуть бути певні епізоди фрінансової кризи, наприклад, спекулятивні “бульбашки”, великі обсяги заборгованості, ризики банкрутства, проблеми ліквідності [4, с. 230].

Сучасні зарубіжні вчені Я. Крегель [5], С. Шрьодер [6], О. Аспечс, Ч. Гудхарт [7] під фінансовою нестабільністю вбачають виняткову подію, яка виявляється внаслідок фрінансових шоків, екзогенних шоків, недосконалості ринків і цінової нестабільності, а найвищою формою її прояву вважають кризу. 
Не всі країни однаково переживають економічний спад і процес посткризового відновлення. Окремі держави та регіони $€$ більш стійкими до економічних і фінансових потрясінь, ніж інші. Після шокових впливів їх економіки не лише повертаються до попереднього рівня розвитку, а й здатні уникати або витримувати такий вплив взагалі. Економісти пов'язують це явище із концепцією стійкості, започаткованою професором економіки Майклом Райхом на початку 2000-х років, в якій "стійкість розглядається як здатність економіки запобігати, протистояти та швидко відновлюватися від дії шокових впливів" [8].

На сьогодні під “стійкістю" економіки розуміють не лише ії̈ здатність повертатися до попереднього рівня розвитку після шокового впливу, а й можливість уникнути або взагалі витримати такий вплив. "Стійкість економіки напряму пов'язується з її здатністю уникати або витримувати шоковий вплив і швидко відновитися в обсягах докризового рівня" [19].

В економічній теорії стійкість $€$ одним із важливих понять економічної рівноваги. Вона характеризує здатність системи зберігати свої властивості в умовах змінного середовища, внутрішніх випадкових або цілеспрямованих трансформацій. Втрата стійкості може настати внаслідок суттєвої зміни параметрів системи, зовнішнього впливу, внаслідок значного або якісно несумісного з існуючою системою впливу, що порушують зв'язки, змінюють її структуру [10, с. 453].

Наявність стану стійкості економіки дає змогу країні мінімізувати негативний вплив шоків і показувати стабільно зростаючу економічну динаміку. Прикладом такої країни може слугувати Польща, національне господарство якої зазнало найменших втрат від кризи 2008-2009 рр. і демонструвало стабільне зростання в подальшому. Саме на прикладі Польщі очевидно, що вплив економічних шоків на стан соціально-економічної системи та її подальший розвиток може бути двояким: або негативним (завдання шкоди економіці), або позитивним (потрясіння сприяють появі нових можливостей для її розвитку). До 2008 р. середні темпи зростання польської економіки були близькими до українських. Проте після кризових шоків 2008-2009 рр. темпи приросту їі ВВП на душу населення значно перевищують відповідні показники в Україні. Серед чинників, які посприяли підвищенню стійкості польської економіки і її динамічному зростанню, можна виокремити створення привабливого інвестиційного клімату 3 великим арсеналом інвестиційних стимулів для іноземних компаній (спеціальні пільгові умови, податкові пільги, урядові гранди, державні дотації тощо). Привабливість країни для іноземних інвесторів базується також на таких важливих чинниках, як:

- макроекономічна стабільність на основі стабільного фінансового розвитку;

- масштабні інвестиції в інфраструктуру країни, переважно із фрондів Євросоюзу;

- гармонійний розвиток різних галузей економіки (різновекторність розвитку економіки), який послаблює залежність від кон'юнктури галузевих ринків;

- висока конкуренція підприємств, яка сприяє підтримуванню високої якості товарів і послуг;

- привабливі умови кредитування для бізнесу;

- міжнародна фрінансова підтримка.

$\mathrm{Ha}$ переконання А. Бойка, забезпечення стійкості національної економіки здійснюється в межах ринкового саморегулювання, державного та суспільного регулювання, природної саморегуляції і саморозвитку [11]. Подібних поглядів дотримується і І. Крючкова, вважаючи, що економіка дедалі більше входить у зону не- 
визначеності і перебуває під прискореним впливом кліматичних, технологічних, політичних, культурних та економічних змін, які підривають стабільність розвитку і постійно несуть в собі певні збурення та потенційні ризики. Дестабілізація однієї складової світового господарства негативно впливає на інші її складові, а покладання кількох важливих компонентів може призвести до руйнівних наслідків за умов низької адаптивності економіки [15]. Таким чином, вони вважають, що чинниками забезпечення стійкості економіки виступають не лише соціально-політичні та економічні чинники, але і природно-екологічні і соціальні. Дестабілізація одного з них може призвести до зниження стійкості економіки і навіть руйнівних наслідків. Підтвердженням цього може слугувати і сучасна пандемія коронавірусу (Covid-19), яка несе не лише руйнівні наслідки для економіки, а й загрозу для життя величезної чисельності населення світу. Спровокувати черговий фрінансовий апокаліпсис можуть і сотні інших чинників, які, за висловлюваннями американського економіста Насіма Талаба, є так званими “чорними лебедями".

Із висновків Європейської комісії, яка займається дослідженням напрямів забезпечення стійкості економіки, її можна досягти шляхом підтримки рівня зайнятості, забезпечення фрінансової стабільності, підтримки регіональної політики з метою подолання диспропорцій у розвитку регіонів, фрінансової допомоги країні у разі виникнення труднощів з бюджетним фінансуванням [20].

$\mathrm{He}$ заперечуючи важливості впливу вищевказаних чинників на забезпечення стійкості економіки, вважаємо, що ключову роль при цьому мають виконувати державні органи управління за рахунок визначених ресурсів і заходів. Саме вони повинні сприяти відродженню економіки, допомагати секторам, а також галузям і регіонам у стабілізації становища та їх адаптації до нових обставин.

Сучасний стан, тенденції розвитку світового господарства і фрінансової системи свідчать про наростання ризиків виникнення та розгортання кризових явищ. В умовах посилення фрінансової нестабільності запобіжником виникнення кризових явищ $€$ підвищення стійкості національної економіки з метою захисту як окремих галузей і секторів економіки, так і народного господарства в цілому. У випадку ж настання шокового впливу на економіку державні органи управління повинні зосередити свої зусилля на прискореній стабілізації ситуації за рахунок передбачених заходів, допомозі господарюючим суб'єктам і галузям адаптуватися до обставин, що склалися, і сприяти швидкому відновленню економіки.

Яскравим прикладом таких дій $€$ рішення лідерів країн “двадцятки” про необхідність підтримки світової економіки в умовах пандемії коронавірусу. В березні 2020 р. під час саміту лідери країн з найбільшими економіками в світі прийняли рішення про підтримку бізнесу і населення своїх країн на безпрецедентну суму - понад 5 трлн дол. США. Вважається, що такі заходи дадуть змогу не допустити суттєвого зменшення обсягів ВВП і зменшити кількість смертей серед населення за рахунок запроваджених карантинних заходів і зростання витрат на сферу охорони здоров'я.

На сьогодні перед урядом і Національним банком України стоїть важливе завдання - з'ясувати процеси, що спричиняють фінансову нестабільність, виробити стратегію і тактику, спрямовані на запобігання i/або подолання цього негативного явища, а також мінімізувати втрати від пандемії коронавірусу. Досягнення стану стабільності фрінансової системи дасть змогу забезпечи- 
ти безперебійне здійснення розрахунків між суб'єктами економіки, підвищити рівень довіри до фрінансових установ, не допустити надмірну волатильність фрінансового ринку, ефективно розподіляти фрінансові ресурси й управляти фрінансовими ризиками, а також створити запас міцності у фрінансовій системі, який дасть можливість протистояти негативним економічним процесам у майбутньому та запобігти їх негативному впливу на економіку.

Висновки. На основі аналізу різноманітних поглядів щодо сутності та чинників фрінансової нестабільності, фрінансової стабільності та стійкості економіки можна зробити певні висновки. Отже, фрінансова нестабільність як явище відображає відхилення фрінансової системи країни від стану динамічної рівноваги під деструктивним впливом внутрішніх і зовнішніх чинників, яке призводить до зниження ефективності виконання покладених на неї функцій і гальмування економічної активності. У свою чергу, фрінансова стабільність - це стан фрінансової системи, при якому вона спроможна витримувати негативний вплив екзогенних чи ендогенних шоків і не допускати серйозних порушень в ії функціонуванні, які могли б призвести до виникнення кризових явищ. Стійкість же економіки пов'язується з її здатністю витримувати негативні шокові впливи, і ця здатність досягається в результаті вдалого поєднання політичних, економічних, соціальних і природно-економічних чинників. Встановлено, що дестабілізація одного із вказаних чинників може суттєво знизити стійкість економіки і призвести до руйнівних наслідків.

Разом з тим, акцентовано увагу на порушенні фрінансової стійкості більшості країн світу та наростанні кризових явищ як у національній, так і у світовій економіці за умов пандемії коронавірусу (Covid-19). Наголошено на важливості надання держав- ної підтримки господарюючим суб'єктам і галузям для їх адаптації до обставин, що склалися, з тим, щоб мінімізувати шоки та спрямувати зусилля на забезпечення фінансової стійкості економіки.

\section{Список використаних джерел}

1. Fisher I. The debt-deflation theory of great depression. Econometrica. 1933. Vol. 1. P. 337-357.

2. Minsky $H$. The financial instability hypothesis: an interpretation of keynes and an alternative to "standard" theory. Nebraska Journal of Economics and Business. 1977. Vol. 16, No 1. P. 5-16.

3. Crockett $A$. The theory and practice of financial stability. GEI News Letter Issue. Global Economic Institutions. 1997. No 6. URL : http://www. cepr.org/gei/6rep2.htm.

4. Lagunoff R. A. Model of financial fragility. Kansas Citi: Journal of Economic Theory. 1998. No 203. 56 p. URL : https://www.kansascityfed.org/ publicat/reswkpap/pdf/rwp98-01.pdf.

5. Kregel J. The natural instability of financial markets. The IDEAs Working Papers Series. 2009. No 4. 24 p.

6. Schroeder S. Defining and detecting financial fragility: New Zeland's experience. International Journal of Social Economics. 2009. Vol. 36, No 3. P. 287-307.

7. Aspachs O., Goodhart C., Tsomocos D., Zicchino $L$. Towards a measure of financial fragility. Annuals of Finance. 2007. No 1. P. 37-74.

8. Reich M. Social structure of accumulation theory: retrospect and prospect. Review of Radical Political Economics. 1997. URL : https://journals. sagepub.com/doi/10.1177/048661349702900301.

9. Белінська Я. В. Механізм забезпечення фрінансової стабільності: структура, інструменти, напрями розвитку. Стратегічні пріориmemu. 2012. № 1 (22). С. 72-84.

10. Фактори макроекономічної нестабільності в системі моделей економічного розвитку : кол. монограср. / за ред. д-ра екон. наук М. І. Скрипниченко. НАН України, Інститут економіки та прогнозування. Київ, 2012. 720 с. 


\section{АКТУАЛЬНІ ПИТАННЯ РОЗВИТКУ ЕКОНОМІКИ}

11. Бойко А. В. Забезпечення стійкості національної економіки. Зовнішня торгівля: економіка, фрінанси, право. 2017. № 4 (93). С. 16-27. URL : http://zt.knteu.kiev.ua/files/2017/04(93)02.pdf.

12. Коваленко В., Гаркуша Ю. Теоретичні та методологічні підходи до оцінювання фрінансової стабільності банківської системи. Вісник НБУ. 2013. № 9. С. 35-40.

13. Унковська T. Є. Системне розуміння фрінансової стабільності: розв'язання парадоксів. Економічна теорія. 2009. № 1. С. 14-33.

14. Шпіка П. Питання фрінансової стабільності в центральних банках. Банки та банківські системи країн світу. 2007. № 3. С. 4-15.

15. Крючкова І. В. Економіка України: шокові впливи та шлях до стабільного розвитку : монографрія. Київ: Інститут економіки та прогнозування НАН України, 2010. 480 c.

16. Deutsche Bundesbank : Financial Stability Review, November 2006. URL : http://www.bundesbank.de/download/volkswirschaft/finanzstabilitaetsberichte/ financialstabilityreview2006.pdf.

17. Padoa-Shioppa T. Central banks and financial stability: exploring a land in between. The transformation of the European financial system. 2002. P. 269-311. URL : https://www.ecb.europa. eu/pub/pdf/other/transformationeuropeanfinancial systemen.pdf.

18. Херреро Г., Симон Н. Иностранные банки и финансовая стабильность в новой Европе. Банки та банківські системи країн cвimy. 2006. № 1. C. 50-59.

19. Annual Growth Survey 2018. European Commission. Brussels: 2017, 15 p. URL : http://ec.europa.eu/info /sites/info /files/2017comm 690 en O.pdf.

20. Economic resilience in EMU. European Commission Directive general economic and financial affairs. 2017. P. 13. URL : http://www.consilium. europa.eu/media/23535/europgroup-15-september.item1-com-note-economic-resilience-emu.pdf.

\section{References}

1. Fisher, I. (1933). The debt-deflation theory of great depression. Econometrica, 1, 337-357.

2. Minsky, H. (1977). The financial instability hypothesis: an interpretation of keynes and an alternative to "standard" theory. Nebraska Journal of Economics and Business, 1, 5-16. (Vol. 16).

3. Crockett, A. (1997). The theory and practice of financial stability. GEI News Letter Issue. Global Economic Institutions, 6. Available at: http://www. cepr.org/gei/6rep2.htm.

4. Lagunoff, R. A. (1998). Model of financial fragility. Kansas Citi: Journal of Economic Theory, 203, 56. Available at: https://www.kansascityfed. org/ publicat/reswkpap/pdf/rwp98-01.pdf.

5. Kregel, J. (2009). The natural instability of financial markets. The IDEAs Working Papers Series, 4, 24.

6. Schroeder, S. (2009). Defining and detecting financial fragility: New Zeland's experience. International Journal of Social Economics, 3, 287307. (Vol. 36).

7. Aspachs, O., Goodhart, C., Tsomocos, D. and Zicchino, L. (2007). Towards a measure of financial fragility. Annuals of Finance, 1, 37-74.

8. Reich, M. (1997). Social structure of accumulation theory: retrospect and prospect. Review of Radical Political Economics. Available at: $\quad$ https://journals. sagepub.com/doi/10.1177/ $\underline{048661349702900301 .}$

9. Belinska, Ya. (2012). Mehanizm zabezpechennia finansovoi stabilnosti: struktura, instrument, napriamy rozvytku [The mechanism of ensuring financial stability: structure, tools, directions of development]. Stratehichni priorytety - Strategic Priorities, 1 (22), 72-84 [in Ukrainian].

10. Skrypnychenko, M. (Ed.). (2012). Faktory makroekonomichnoi nestabilnosti $v$ systemi modeley ekonomichnoho rozvytku [The macroeconomic instability factors in the system of economic development models]. Kyiv: NAS of Ukraine, Institute of Economics and Forecasting [in Ukrainian]. 


\section{АКТУАЛЬНІ ПИТАННЯ РОЗВИТКУ ЕКОНОМІКИ}

11. Boyko, A. V. (2017). Zapezpechennia stiykosti natsionalnoi ekonomiky [Ensuring the stability of the national economy]. Zovnishnia torhivlia: ekonomika, finansy, pravo - External Trade: Economics, Finance, Law, 4 (93), 16-27. Available at: http://zt.knteu.kiev.ua/files/2017/04(93)02.pdf.

12. Kovalenko, V., Harkusha, Yu. (2013). Teoretychni ta metodolohichni pidhody do otsiniuvannia finansovoi stabilnosti bankivskoi systemy [Theoretical and methodological approaches to assessing the financial stability of the banking system]. Visnyk NBU - Bulletin of the National Bank of Ukraine, 9, 35-40 [in Ukrainian].

13. Unkovska, T. (2009). Systemne rozuminnia finansovoi stabilnosti: rozviazannia paradoksiv [Systematic understanding of financial stability: solving paradoxes]. Ekonomichna teoria - Economic Theory, 1, 14-33 [in Ukrainian].

14. Shpika, P. (2007). Pytannia finansovoi stabilnosti $v$ tsentralnyh bankah [The issue of financial stability in central banks]. Banky ta bankivski systemy krain svitu - Banks and Banking Systems of the World's Countries, 3, 4-15 [in Ukrainian].

15. Kriuchkova, I. (2010). Ekonomika Ukrainy: shokovi vplyvy ta shliah do stabilnoho rozvytku [The Ukrainian economy: shock effects and a way to stable development]. Kyiv: Institute of economics and forecasting NAS of Ukraine [in Ukrainian].
16. Deutsche Bundesbank: Financial Stability Review, November 2006. Available at: http://www. bundesbank.de/download/volkswirschaft/finanzstabilitaets berichte/financialstabilityreview2006.pdf.

17. Padoa-Shioppa, T. (2002). Central banks and financial stability: exploring a land in between. The transformation of the European financial system, 269-311. Available at: https://www.ecb.europa.eu/pub/pdf/other/transformationeuropean financialsystemen.pdf.

18. Herreho, H., Symon, N. (2006). Inostrannyye banki $i$ finansovaya stabilnost $v$ novoy Yevrope [Foreign banks and financial stability in the new Europe]. Banky ta bankivski systemy krain svitu - Banks and Banking Systems of the World's Countries, 1, 50-59 [in Russian].

19. Annual Growth Survey 2018. European Commission. Brussels: 2017, 15 p. Available at: http://ec.europa.eu/info /sites/info /files/2017comm 690 en O.pdf.

20. Economic resilience in EMU (2017). European Commission Directive general economic and financial affairs, 13. Available at: http://www.consilium. europa.eu/media/23535/europgroup-15-september. item1-com-note-economic- resilience-emu.pdf.

Стаття надійшла до редакції 29.02.2020. 